\title{
Some Adsorption Characterizations of the Egyptian Glauconite Ore
}

\author{
M.A. Eid \\ Department of Soil Science, Faculty of Agriculture, Ain Shams \\ Univeristy, Cairo, Egypt.
}

ANY industrials use different adsorbent agents in purification
of the liquid products or the wastewater. The use of natural
materials as low coast sorbents for the removal of cations, especially
heavy metals from aqueous solutions has recently received increasing
attention. The present study was conducted to evaluate the some
adsorption properties of the Egyptian glauconite ore. Batch
equilibrium experiments were conducted using Cu (II), Fe (II) or Ca
(II) with glauconite. The results reveal that the thermodynamic
equilibrium of $\mathrm{Cu}$ (II), Fe (II) or Ca (II) with glauconite is attained at
20 min the curves obtained are single and smooth indicating the
formation of monolayer of cations on the adsorbent surface of
glauconite. The pH is one of the most important factors that affect the
adsorption process. The maximum removals of Cu (II), Fe (II) or Ca
(II) with glauconite are at pH $6,5.5$ and 8 , respectively. The process
of different cations uptake follows both Langmuir and Freundlich
isotherm models and the first-order kinetics. The values of Langmuir
constants for glauconite $Q_{\text {max }}$ and b were found to be equal $3.76,4.61$
and $6.32 \mathrm{mg} / \mathrm{g}$ and 0.215 , 0.046 and $0.0621 / \mathrm{mg}$, for Cu (II), Fe (II)
and Ca (II) respectively. Based on the results of the present study,
glauconite can be use as low coast cations adsorbent agent. Especially
it has a big advantage that is the sandy loam textural makes the
glauconite use also as a sand filter.

Keywords: Adsorption, Glauconite, Heavy metals, Copper, Iron, Calcium, Langmuir and Freundlich isotherm models, First-order kinetics.

The naturally occurring iron-potassium silicate "greensand" is also called glauconite $(\mathrm{K}, \mathrm{Na})(\mathrm{Al}, \mathrm{Fe}, \mathrm{Mg})_{2}(\mathrm{Al}, \mathrm{Si})_{4} \mathrm{O}_{10}(\mathrm{OH})_{2}$. A widely held concept is that glauconitization starts from a K-poor glauconitic smectite, which progressively evolves toward an end member constituted by a K-rich glauconitic mica (Odin and Matter, 1981). On the basis of their potassium content, glauconitic grains are ranked as nascent $\left(\mathrm{K}_{2} \mathrm{O}<4 \%\right)$, slightly evolved (4-6\%), evolved (6-8\%), and highly evolved $(>8 \%)$. According to Odin and Létolle (1980) and Odin and Matter (1981), the term glauconite should be restricted to a dark green, mica-type glauconitic mineral, whereas the general term glaucony should be used to designate green pellets enriched in glauconitic minerals, especially when precise mineralogical connotation is lacking. (Amorosi et al., 2007).

mohamed_eid@agr.asu.edu.eg 
In Egypt, Glauconites occur in the Western Desert associated with phosphorites and iron ores (Baioumy, 2007). According to El-Aref et al. (1999) the thickness of the overlying glauconitic sediments varies in thickness from up to $25 \mathrm{~m}$ in the Western and Eastern Wadis areas to less than $1 \mathrm{~m}$ in the high central area, El-Gideda mine of the Bahria Oasis.

Glauconite used as a substrate for growing agricultural plants (Pishmanov and Petkova, 2002), as soil amendment (Heckman and Tedrow, 2004), source of potassium for growing crops (Rao, and Rao, 1999 and Eid, 2012) or as low coast sorbent agent. Smith et al. (1996), evaluated adsorption equilibria for Cd(II), $\mathrm{Pb}(\mathrm{II})$ and $\mathrm{Zn}$ (II) on a sample of pass 200 mesh Lithuanian glauconite. They recorded that the relative adsorption capacity for the metals was in the order $\mathrm{Pb}>$ $\mathrm{Cd}>\mathrm{Zn}$. Although glauconite is a complex clay mineral, a single site approach provided a satisfactory description for many of the cases studied. Henriksen $e t$ al. (1998) investigated the possibility of segregating liquid manure so that all the $\mathrm{N}$ is transferred into a thick slurry phase by different natural and synthetic adsorpents, in order to allow the remaining liquid to be spread onto fields without causing environmental problems. They recorded that the clinoptilolite showed the highest capacity for ion exchange but glauconite was preferred due to its faster reaction time. Petkova et al. (2000) tested a zeolite - glauconite phosphorite mixtures for decrease of lead uptake by plants. They found that the input of zeolite-glauconite and zeolite-phosphorite compositions did not result in soil acidity neutralization but resulted in decreasing lead content of radishes by approximately two times compared to radishes grown on contaminated soil, which is due to their high ion exchange capacity and hemosorption. Lukiyanik et al. (2001) used a natural sorbents for decalcination of purified juice. They suggested that the natural adsorbent separated glauconite should be used for softening of sugarbeet juices. Ringqvist et al. (2002) determine metal adsorption from wastewaters onto sphagnum and carex (peat samples) and compare it to the adsorption onto peat granules, clinoptilolite, glauconiteand and a flue dust from steel production. They reported that the combination of glauconite or clinoptilolite with the peat samples in column experiments gave a minor improvement in metal removal. The responses of calves receiving feed contaminated with radionuclides and heavy metals to the addition of glauconite to he basic ration as enterosorbents was studied by Fomichev et al. (2005). They concluded that the use of glauconite as enterosorbents of radionuclides and heavy metals for raising calves in Russia is effective.

The present study was conducted to evaluate the adsorption properties of Egyptian glauconite ore as a natural low coast sorbent agent.

\section{Material and methods}

\section{Characterization of the adsorbent}

The glauconite ore was obtained from the Central Metallurgical Research and Development Institute, Helwan, Cairo, Egypt, that was taken from Bahariya

Egypt. J. Soil Sci. 53, No. 1 (2013) 
Oasis, Egypt. Characterizations of some physical and chemical properties of glauconite ore were determined with the standard methods according to Page et al. (1982) and the results were listed in Table 1.

TABLE 1. Some physical and chemical properties of glauconite ore.

\begin{tabular}{|lcc|}
\hline Characteristic & Units & Glauconite \\
\hline Sand & $\%$ & 69.3 \\
Silt & $\%$ & 17.2 \\
Clay & $\%$ & 13.5 \\
Textural class & $\%$ & Sandy Loam \\
Saturation & $\mathrm{dS} / \mathrm{m}$ & 70 \\
EC & & 7.03 \\
Soil saturation extract & & \\
pH & $\%$ & 3.67 \\
Soil paste & $\%$ & \\
CaCO & $\mathrm{mg} / \mathrm{kg}$ & 0.1 \\
Organic matter & $\%$ & 0.12 \\
Total N & & 168 \\
Total K & & 2.5 \\
Cation Exchange capacity & $\mathrm{Meq} / 100 \mathrm{~g}$ & 48.5 \\
Exchangeable Ca & & 8.2 \\
Exchangeable $\mathrm{Mg}$ & & 2.5 \\
Exchangeable Na & & 2.7 \\
Exchangeable K & & 32.6 \\
\hline
\end{tabular}

\section{Procedure for adsorption measurement}

A stock solution $(1000 \mathrm{mg} / \mathrm{l})$ of $\mathrm{Cu}$ (II), Fe (II) or Ca (II) was prepared by dissolving accurate weight of $\mathrm{CuSO}_{4} \cdot 5 \mathrm{H}_{2} \mathrm{O}, \mathrm{FeSO}_{4} \cdot 7 \mathrm{H}_{2} \mathrm{O}$ or $\mathrm{CaCl}_{2} \cdot 2 \mathrm{H}_{2} \mathrm{O}$, respectively in definite volume of distilled water. Proper concentrations of the adsorbate were prepared from the stock solution through proper dilution. The $\mathrm{pH}$ of the adsorbate was adjusted during the dilution step using diluted hydrochloric acid or sodium hydroxide to study the effect of $\mathrm{pH}$ factor on the adsorption process. The $\mathrm{pH}$ of the solution was measured with a WPA CD720 pH meter. Adsorption measurements were made in triplicate by the batch technique at room temperature $\left(25 \pm 2{ }^{\circ} \mathrm{C}\right)$. A shaker model Gerhardt LS20 was used for shaking the adsorption batches (shaking rate $200 \mathrm{rpm}$ ). At the end of a predetermined time interval, the adsorbent was removed by filtration. The concentrations of solutions before and after adsorption were measured by using a flame atomic absorption spectrometer, Varian AA-20. The working standards for calibration of the atomic absorption spectrophotometer were prepared by diluting a stock solution of $1000 \mathrm{mg} / \mathrm{l}$ cations. Fresh calibration was done before the analysis of each batch of samples for cation determination. The percent adsorption was estimated by employing the following expression (Milonjic et al., 1992).

\section{$\%$ Removal $=\left(C_{0}-C_{\mathrm{e}} / C_{0}\right) \times 100$}

where $C_{0}$ and $C_{\mathrm{e}}$ are the initial and the equilibrium cation concentrations, respectively. The effect of contact time (2-120 $\mathrm{min})$, the adsorbent dosage (0.5-6 g/50ml) and $\mathrm{pH}$ profile [1- 6 for $\mathrm{Cu}$ (II) and $\mathrm{Fe}$ (II) and of $1-8$ for $\mathrm{Ca}$ (II)] 
in adsorbate concentration $(100 \mathrm{mg} / \mathrm{l})$ were investigated. Also, kinetic studies and adsorption isotherm of adsorbate concentration $(50-300 \mathrm{mg} / \mathrm{l})$ on the adsorption process, as well as to what extent the adsorption data obey Langmuir and Freundlich adsorption isotherms were studied.

\section{Results and discussion}

\section{Effect of agitation time}

Time taken for the adsorption process to attain thermodynamic equilibrium is very important in characterization and prediction of both the efficiency and the feasibility of an adsorbent for its use in water pollution control or in the other usages. The effect of agitation time was studied for $100 \mathrm{mg} / \mathrm{l}$ adsorbate concentrations. Fig. 1 shows that the percentage of $\mathrm{Cu}$ (II), $\mathrm{Fe}$ (II) or $\mathrm{Ca}(\mathrm{II})$ removal increases sharply with increasing agitation time up to $10 \mathrm{~min}$ and then it increases very slowly and becomes nearly constant after $20 \mathrm{~min}$ The constant percent removal after 20 min means that thermodynamic equilibrium is attained at that extent. Henriksen et al. (1998) investigated the possibility of segregating liquid manure so that all the $\mathrm{N}$ is transferred into a thick slurry phase by different natural and synthetic adsorpents, in order to allow the remaining liquid to be spread onto fields without causing environmental problems. They recorded that the clinoptilolite showed the highest capacity for ion exchange but glauconite was preferred due to its faster reaction time. It is clear from Fig. 1 that the lower the adsorbate concentration, the higher the percent cations removal and this is a benefit because, as example, industrial wastewater is actually a very diluted solution of different pollutants. The curves obtained are single and smooth indicating the formation of a monolayer of cations on the adsorbent surface. Smith et al. (1996) found the same result. They evaluated adsorption equilibria for $\mathrm{Cd}(\mathrm{II}), \mathrm{Pb}(\mathrm{II})$ and $\mathrm{Zn}(\mathrm{II})$ on a glauconite and recorded that although glauconite is a complex clay mineral, a single satisfactory description for many of the cases studied. site approach provided a single site approach provided a satisfactory description for many of the cases studied.

\section{Effect of adsorbent dose}

The dependence of cations removal on adsorbent dose was investigated by varying the amount of glauconite from 0.5 to $6 \mathrm{~g} / 50 \mathrm{ml}$, while keeping other parameters $(\mathrm{pH}$, agitation speed and time and adsorbate concentration) constant. Fig. 2 shows the dependence of cations removal extent on the adsorbent dose. It is clear from the figure that the extent of $\mathrm{Cu}$ (II) and $\mathrm{Fe}$ (II) removal increases by increasing glauconite dose. This can be explained on the bases that the higher adsorbent dose in the adsorbate solution, the greater the availability of exchangeable sites for $\mathrm{Cu}$ (II) and $\mathrm{Fe}$ (II) ions. Such effect was true for $\mathrm{Ca}$ (II) below $4 \mathrm{~g}$ of adsorbent dose, where increasing glauconite dose decreased the percentage removal of $\mathrm{Ca}$ (II). This may be resulted from the exchangeable of $\mathrm{H}$ cations of solution with exchangeable Ca of glauconite (glauconite had 8.2 meq. $\mathrm{Ca} / 100 \mathrm{~g}$, Table 1). 


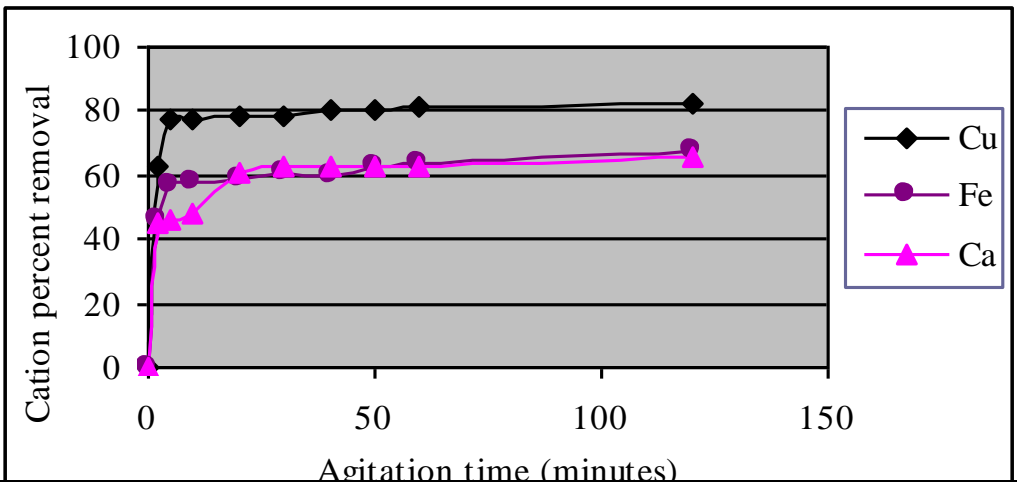

Fig.1. Effect of agitation time on cation adsorption onto glauconite. A dsorbent dose, $1 \mathrm{~g} / 50 \mathrm{ml}, 100 \mathrm{mg}$ cation $/ 1$, pH 4.4 .

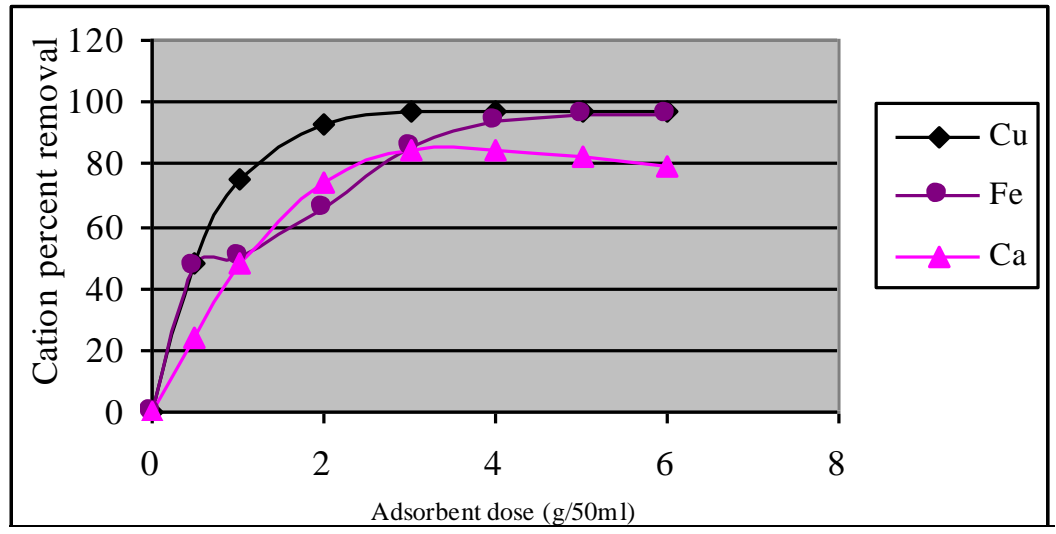

Fig. 2. Effect of adsorbent dose on cation a dsorption onto glauconite. Agitation time $20 \mathrm{~min}, 100 \mathrm{mg}$ cation/1, $\mathrm{pH} 4.4$.

\section{Effect of $p H$}

Initial $\mathrm{pH}$ is one of the most important factors that affect the adsorption process. It affects not only the surface charge of the adsorbent, but also the ionization degree of the adsorbate. To investigate the role of $\mathrm{pH}$ in $\mathrm{Cu}$ (II) or $\mathrm{Fe}$ (II) removal efficiency, the initial $\mathrm{pH}$ of the adsorbate solution was varied in the range of $1-6$. The adsorption study could not be carried out experimentally at $\mathrm{pH}$ values higher than 6 due to the precipitation of copper or iron hydroxide above this $\mathrm{pH}$ range. While the $\mathrm{pH}$ of $\mathrm{Ca}$ (II) solution increased up to 8 .

Figure 3 shows the percent of cations removal as a function of $\mathrm{pH}$. It can be seen that the percentage of $\mathrm{Cu}$ (II), $\mathrm{Fe}$ (II) and $\mathrm{Ca}$ (II) removal is maximum 
(83.5\%), (90.5\%) and (74.2\%) at $\mathrm{pH} 6,5.5$ and 8, respectively. Silber et al. (2012) recorded that zinc adsorption by perlite was dependent on $\mathrm{pH}$, it involved a combination of specific chemical affinity to adsorption sites and an electrostatic component that is related to the surface charge and is controlled by $\mathrm{pH}$. Elevating temperature significantly and systematically raised the $\mathrm{pH}$ and enhanced $\mathrm{Zn}$ adsorption. Abdel-Halim and Al-Deyab (2011) found that adsorption of $\mathrm{Zn}$ (II) ions onto acidified sodium alginate (ASA) was $\mathrm{pH}$ dependent and maximum adsorption was obtained at $\mathrm{pH}$ 6. At $\mathrm{pH}$ values less than 4 , the percent removal decreases continuously until it vanishes about $11 \%$, $0.0 \%$ and $0.0 \%$ for $\mathrm{Cu}$ (II), Fe (II) and $\mathrm{Ca}$ (II) at $\mathrm{pH} 1$, respectively.

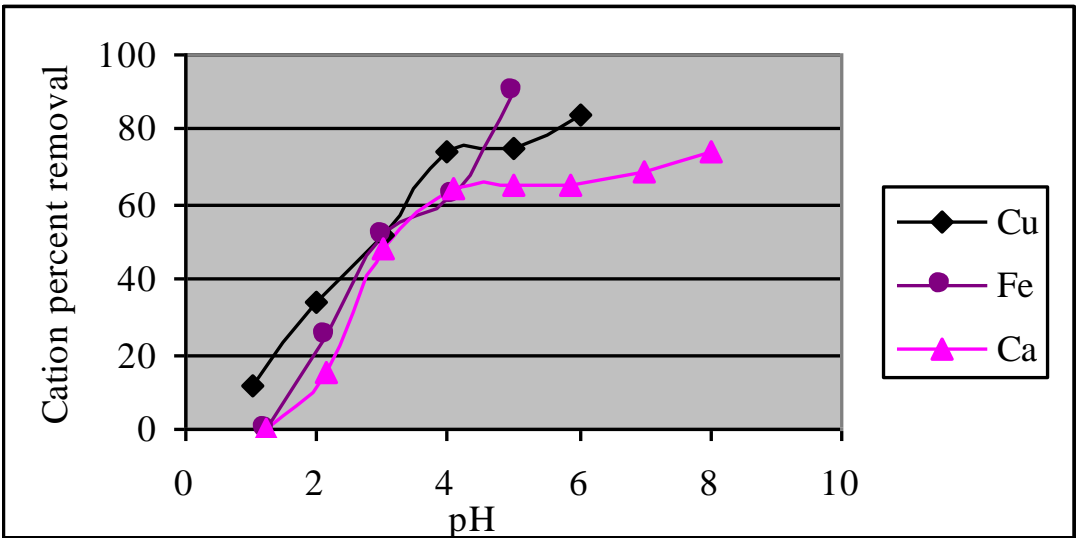

Fig. 3. Effect of pH on cation adsorption onto glauconite. (Agitation time 20 min, Adsorbent dose 1g/50ml, 100mg cation/1).

The low percent removal at $\mathrm{pH} \leq 1$ can be attributed to both the fact that at, the high concentration of $\mathrm{H}^{+}$in the adsorption medium and to the protonation of ion exchange sites on glauconite surface. Under such conditions, the metal ions do not exchange and remain in the solution. As the $\mathrm{pH}$ value increases, the deprotonation of the glauconite surface increase and as a result, the adsorption capacity increases.

\section{Adsorption isotherms and kinetic studies}

The relation between cations equilibrium concentration and its extent of removal from aqueous solutions was studied at various cation concentrations and at fixed adsorbent dose. Adsorption data for a wide range of adsorbate concentrations is the most commonly described by adsorption isotherms, such as Langmuir or Freundlich isotherms, which relate adsorption density, $q_{e}$ (adsorbate uptake per unit weight of the adsorbent) to equilibrium adsorbate concentration in the bulk fluid phase $\left(C_{e}\right)$. 
According to Langmuir (1918), maximum adsorption corresponds to a saturated monolayer of adsorbate molecules on the adsorbent surface. The linear form of Langmuir isotherm is given by the following equation:

$$
\frac{C_{\mathrm{e}}}{q_{\mathrm{e}}}=\left(\frac{1}{Q_{\max } \times b}\right)+\left(\frac{C_{\mathrm{e}}}{Q_{\max }}\right)
$$

where $C_{e}$ is the equilibrium concentration of adsorbate (mg/l), $q_{e}$ is the amount of metal adsorbed at equilibrium $(\mathrm{mg} / \mathrm{g})$ and $Q_{\max }(\mathrm{mg} / \mathrm{g})$ and $\mathrm{b}(1 / \mathrm{mg})$ are the Langmuir constants related to the adsorption capacity and energy, respectively.

The adsorption process was found to obey Langmuir adsorption isotherm, thus on plotting $C_{e}$ versus $C_{e} / q_{e}$ (Fig. 4, 5 and 6) a straight line with correlation coefficient $\left(\mathrm{R}^{2}\right)$ of $0.9977,0.9887$ and 0.9987 for $\mathrm{Cu}$ (II), Fe (II) and $\mathrm{Ca}$ (II), respectively were obtained. The values of Langmuir constants for glauconite $Q_{\max }$ and b were calculated and found to be equal $3.76,4.61$ and $6.32 \mathrm{mg} / \mathrm{g}$ and $0.215,0.046$ and $0.0621 / \mathrm{mg}$, for $\mathrm{Cu}$ (II), Fe (II) and Ca (II), respectively.

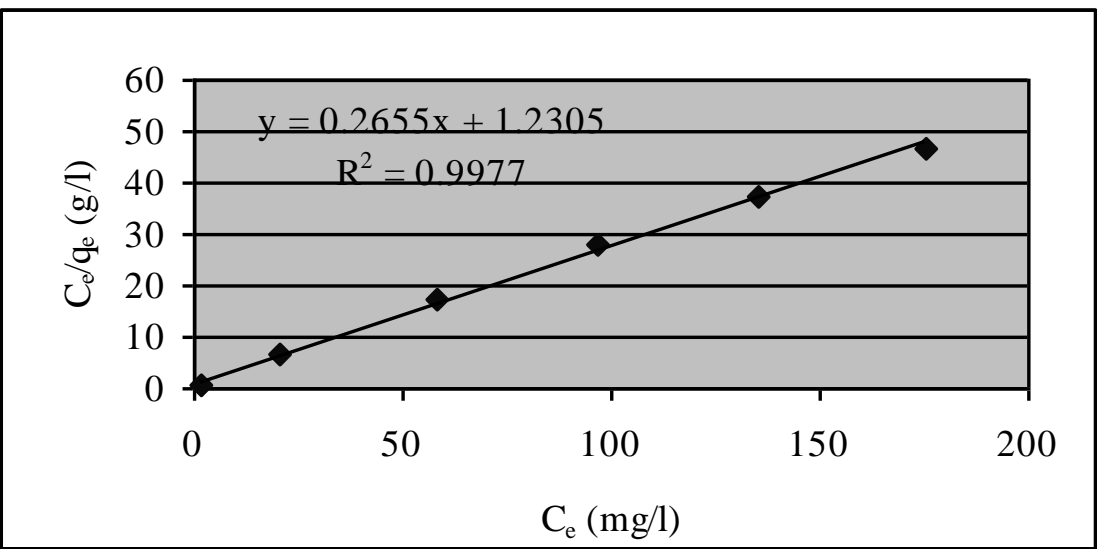

Fig. 4. Langmuir adsorption isotherm of $\mathrm{Cu}$ (II) onto glauconite.

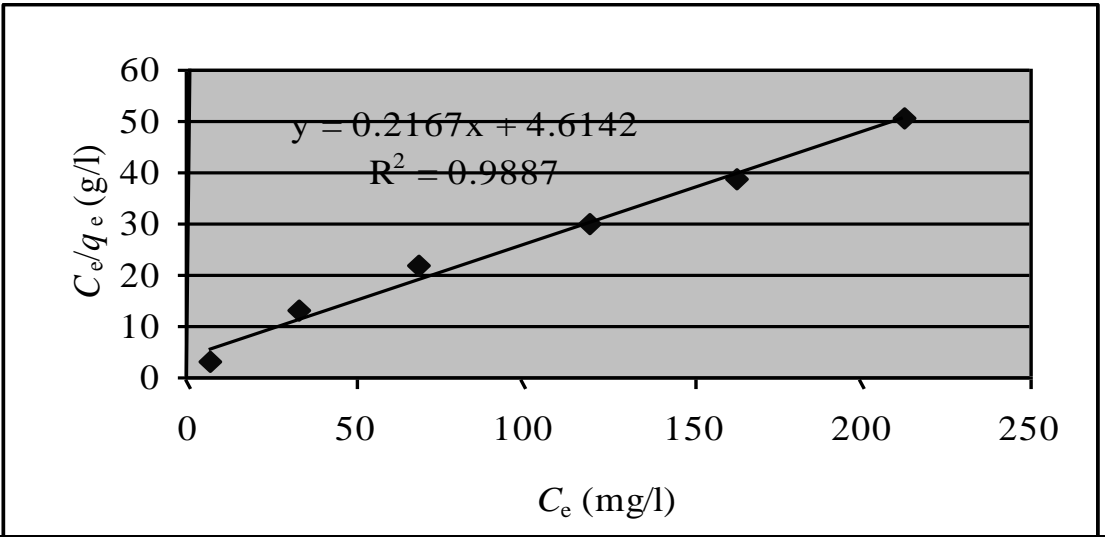

Fig. 5. Langmuir adsorption isotherm of $\mathrm{Fe}$ (II) onto glauconite. 


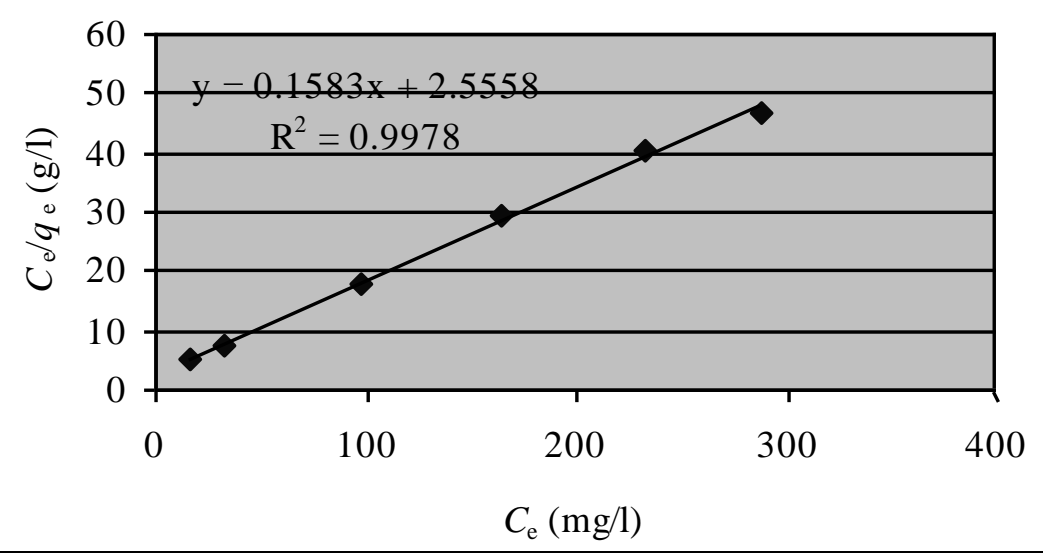

Fig. 6. Langmuir adsorption isotherm of $\mathrm{Ca}$ (II) onto glauconite.

The essential characteristics of Langmuir can be expressed in terms of a dimensionless equilibrium parameter, RL, which describes the type of isotherm (Hall et al., 1966) and is defined by:

$$
R_{\mathrm{L}}=\frac{1}{1+b \times C_{0}}
$$

where $b(1 / \mathrm{mg})$ is the Langmuir constant and $C_{0}(\mathrm{mg} / \mathrm{l})$ is the initial concentration of cation solution. The parameter RL shows the shape of isotherm according to Table 2. The values of $\mathrm{RL}$ for different $\mathrm{Cu}$ (II), Fe (II) and $\mathrm{Ca}$ (II) initial concentrations are listed in Table 3. It is clear from Table 2, all RL values range between 0 and 1, indicating the favorable adsorption of $\mathrm{Cu}$ (II), $\mathrm{Fe}$ (II) and $\mathrm{Ca}$ (II) onto glauconite.

Table 2. Effect of separation factor, RL on isotherm shape.

\begin{tabular}{|cc|}
\hline RL value & Type of isotherm \\
\hline $\mathrm{RL}>1$ & Unfavorable \\
$\mathrm{RL}=1$ & Linear \\
$0<\mathrm{RL}<1$ & Favorable \\
$\mathrm{RL}=0$ & Irreversible \\
\hline
\end{tabular}

Table 3. RL values based on Langmuir equation for $\mathrm{Zn}$ (II) adsorbed on ASA.

\begin{tabular}{|llll|}
\hline Cation concentration (mg/l) & Cu (II) RL value & Fe (II) RL value & Ca (II) RL value \\
\hline 50 & 0.085 & 0.303 & 0.243 \\
100 & 0.044 & 0.178 & 0.139 \\
150 & 0.030 & 0.127 & 0.097 \\
200 & 0.022 & 0.098 & 0.075 \\
250 & 0.018 & 0.080 & 0.061 \\
300 & 0.010 & 0.068 & 0.051 \\
\hline
\end{tabular}

Egypt. J. Soil Sci. 53, No. 1 (2013) 
Moreover, the adsorption process was also found to obey Freundlich adsorption isotherm (Freudlich, 1907), thus on plotting $\log C_{\mathrm{e}}$ against $\log q_{\mathrm{e}}$ (Fig. 7, 8 and 9) a straight line with a correlation coefficient $\left(\mathrm{R}^{2}\right)$ of $0.9704,0.9978$ and 0.9947 were obtained for $\mathrm{Cu}$ (II), Fe (II) and Ca (II), respectively. Freunlich isotherm is represented by the equation:

$$
\log q_{\mathrm{e}}=\log K_{\mathrm{F}}+(1 / n) \log C_{\mathrm{e}}
$$

where $q_{\mathrm{e}}$ is the amount of adsorbate adsorbed per unit weight of adsorbent $(\mathrm{mg} / \mathrm{g}), C_{\mathrm{e}}$ is the equilibrium adsorbate concentration $(\mathrm{mg} / \mathrm{l})$, and $K_{\mathrm{F}}$ and $n$ are Freundlich constants, related to capacity of adsorbent and favorability of the adsorption, respectively. The values of Freundlich constants for glauconite, $K_{\mathrm{F}}$ were calculated and found to equal $1.945,1.073$ and 1.913 for $\mathrm{Cu}$ (II), Fe (II) and $\mathrm{Ca}$ (II), respectively. As shown from the results, the values of $n$ are 7.662, 1.353 and 1.267 for $\mathrm{Cu}$ (II), Fe (II) and Ca (II), respectively, (i.e., $0<\mathrm{n}<10$ ) showing that the adsorption of this cations onto glauconite is favorable.

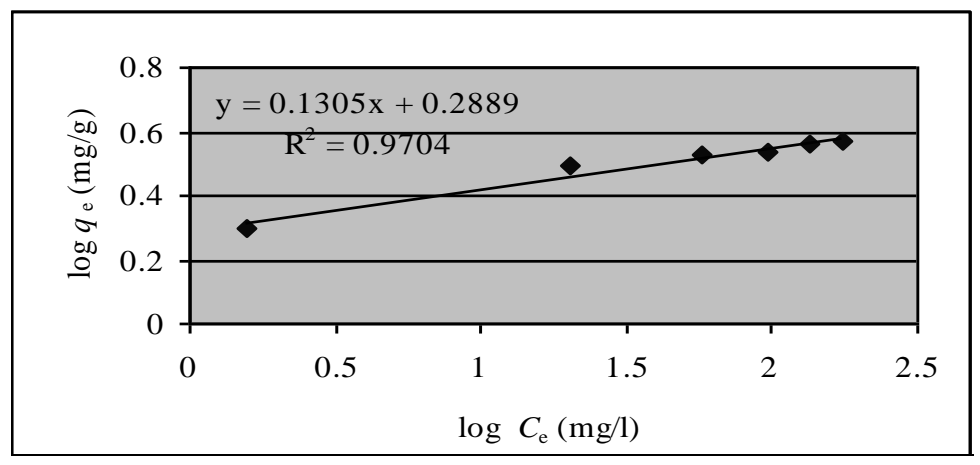

Fig. 7. Freundlich adsorption isotherm of $\mathrm{Cu}$ (II) onto glauconite.

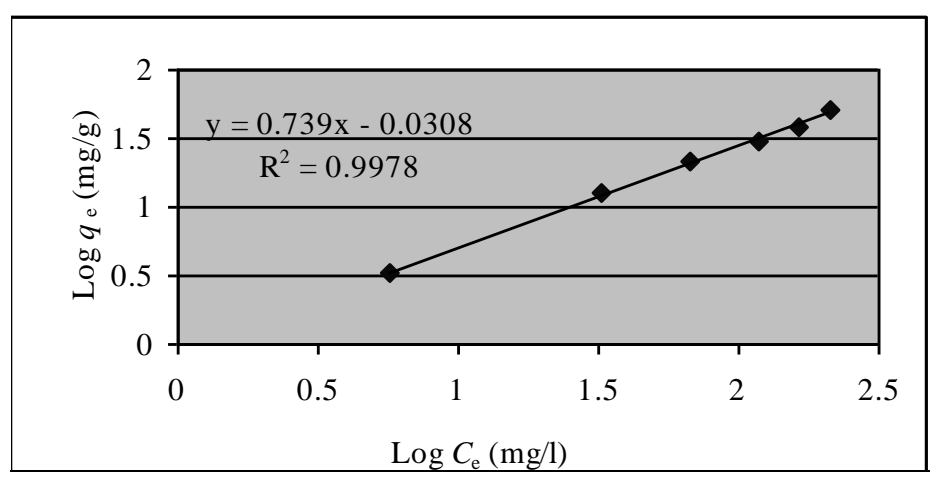

Fig. 8. Freundlich adsorption isotherm of Fe (II) onto glauconite. 


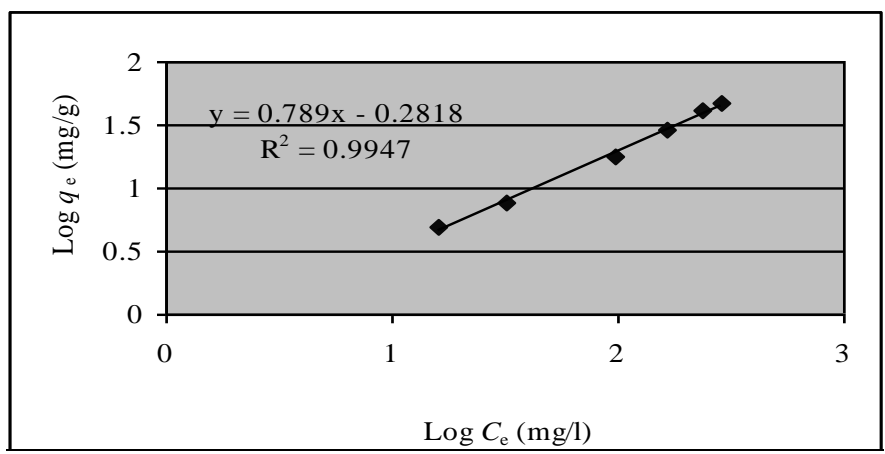

Fig. 9. Freundlich adsorption isotherm of $\mathrm{Ca}$ (II) onto glauconite.

The rate constants of adsorption $\left(K_{\mathrm{ad}}\right)$ for cation removal from solution by glauconite were determined by using the following first-order rate expression by Lagergren (Singh et al., 1996 a and 1996 b).

$$
\log \left(q_{e}-q\right)=\log q_{e}-\left(K_{\mathrm{ad}} / 2.303\right) \mathrm{X} \mathrm{t}
$$

where $q_{e}$ and $q$ (both in $\mathrm{mg} \mathrm{g}^{-1}$ ) are the amount of $\mathrm{Cu}$ (II), Fe (II) or Ca (II) adsorbed at equilibrium and any time, $\mathrm{t}$, respectively.

The linearity of the plot $\log \left(q_{e}-q\right)$ versus $t$ (Fig. 10) indicates the applicability of the first-order rate expression. A straight line with a correlation coefficient $\left(\mathrm{R}^{2}\right)$ of $0.7949,0.9318$ and 0.7575 for $\mathrm{Cu}$ (II), Fe (II) and Ca (II), respectively were obtained. The $K_{\text {ad }}$ values, calculated from the slope of the lines in Fig. 10 are $34.8 \times 10^{-3}, 20.7 \times 10^{-3}$ and $36.4 \times 10^{-3} \mathrm{~min}^{-1}$ for $\mathrm{Cu}$ (II), $\mathrm{Fe}$ (II) or Ca (II), respectively. Tahir and Rauf (2004) reported that the bentonite clay has been used for the adsorption of $\mathrm{Fe}(\mathrm{II})$ from aqueous solutions over a concentration range of $80-200 \mathrm{mg} / \mathrm{l}$, shaking time of 1-60 min, adsorbent dosage from 0.02 to $2 \mathrm{~g}$ and $\mathrm{pH}$ of 3 . The process of uptake follows both the Langmuir and Freundlich isotherm models and also the first-order kinetics and the $K_{\text {ad }}$ of Fe (II) on bentonite was $19.4 \times 10^{-3} \mathrm{~min}^{-1}$.

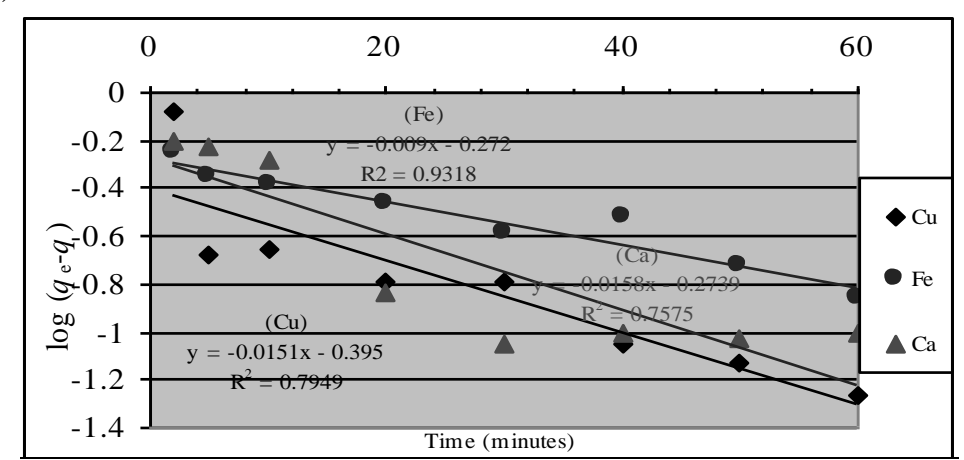

Fig. 10. Lagergren plot for the adsorption of different cations on glauconite (adsorbent dose, $1 \mathrm{~g} / 50 \mathrm{ml}, 100 \mathrm{mg}$ cation/1, $\mathrm{pH}$ 4.4).

Egypt. J. Soil Sci. 53, No. 1 (2013) 
It could be concluded that the adsorption of $\mathrm{Cu}, \mathrm{Fe}$ and $\mathrm{Ca}$ cations on glauconite is dependent on the $\mathrm{pH}$, time and the dose of the adsorbent. The adsorption process was also found to obey Langmuir and Freundlich isotherm models. The values of Langmuir constants for glauconite $Q_{\max }$ and b were found to be equal 3.76, 4.61 and $6.32 \mathrm{mg} / \mathrm{g}$ and $0.215,0.046$ and $0.0621 / \mathrm{mg}$, for $\mathrm{Cu}$ (II), Fe (II) and $\mathrm{Ca}$ (II), respectively. The values of Freundlich constant for glauconite, $K_{\mathrm{F}}$ were found to equal $1.945,1.073$ and 1.913 for $\mathrm{Cu}$ (II), $\mathrm{Fe}$ (II) and $\mathrm{Ca}$ (II), respectively. It clear that glauconite is efficient as an adsorbent agent for a heavy metals.

\section{References}

Abdel-Halim, E. And Al-Deyab, S. (2011) Removal of heavy metals from their aqueous solutions through adsorption onto natural polymers. Carbohydrate Polymers 84: (1) 454-458.

Amorosi, A., Sammartino, I. and Tateo, F. (2007) Evolution patterns of glaucony maturity: A mineralogical and geochemical approach. Deep Sea Research Part II: Topical Studies in Oceanography 54: 1364-1374.

Baioumy, H.M. (2007) Iron-phosphorus relationship in the iron and phosphorite ores of Egypt. Chemie der Erde - Geochemistry 67: 229-239.

Eid, M. A. (2012) Success usage for the glauconite ores as a natural Egyptian potassium fertilizer source. Egyptian J. Soil. Sci. (Under Press).

El-Aref, M. M., El-Sharkawi, M. A. and Khalil, M.A. (1999) The geology and genesis of stratabound to stratiform Cretaceous-Eocene iron ore deposits of El Bahariya Region, Western Desert, Egypt. International Conference on Geol. Arab World (GAW4), pp. 450-475.

Fomichev, Y., Strekozov, N., Shaidullina, R., Strekozova, E., Donnik, I., Khaibullin, R., Fedorov, Y. and Severov, V. (2005) Effectiveness of using enterosorbents in raising young cattle in technogenic zones of Russia. Russian Agricultural Sciences $\mathbf{6}$ : $7-14$.

Freudlich, H. (1907) Ueber die Adsorption in Loesungen. Journal of Physical Chemistry 7: $385-470$.

Hall, K., Eagleton, L., Acrivos, A. and Vermevlem, T. (1966) Pore and solid diffusion kinetics in fixed bed adsorption under constant pattern conditions. Industrial \& Engineering Chemistry Fundamentals 5: 212-219.

Heckman, J. R. and J. C. Tedrow. (2004) Greensand as a soil amendment. Better Crops With Plant Food 88: 16-17.

Henriksen, K., Berthelsen, L. and Matzen, R. (1998) Separation of liquid pig manure by flocculation and ion exchange. Part 1: laboratory experiments. Journal of Agricultural Engineering Research 69 (2): 115-125. 
Langmuir, I. (1918) The adsorption of gases on plane surfaces of glass, mica and platinum. Journal of the American Chemical Society 40: 1361-1403.

Lukiyanik, O., Kupchik, M., Mank, V., Reva, L., Simakhina, G. and Martsin, I. (2001) Use of natural sorbents for decalcination of purified juice. Tsukor Ukraini 2 (1): 28-30.

Milonjic, S., Boskovic, M. and Ceranic, T. (1992) Adsoprtion of uranium(VI) and zirconium (IV) from acid solutions on silica gel. Sep. Sci. Technol. 27: 1643-1653.

Odin, G. and Matter, A. (1981) De glauconiarum origine. Sedimentology 28: 611-641.

Odin, G. and Létolle, R. (1980) Glauconitization and phospatization environments: a tentative comparison. SEPM Special Publication 29: 227-237

Page, A.L., Miller, R.H. and Keeny, D.R. (1982) "Methods of Soil Analysis", $2^{\text {nd }}$ ed., American Society of Agronomy, Inc. Soil Sci. Society of American, Inc. Publisher, Madison, Wisconsin, USA.

Petkova, D., Popandova, S., Popova, T. and Chakalov, K. (2000) Testing of zeoliteglauconite - phosphorite mixtures for decrease of lead uptake by plants. Bulgarian Journal of Agricultural Science 6 (3): 321-326.

Pishmanov, N. and Petkova, D. (2002) Nutrient uptake by glauconite-phosphorite rock materials. Pochvoznanie, Agrokhimiya i Ekologiya. National Centre for Agrarian Sciences in Bulgaria, Sofia, Bulgaria. 37: 161-163.

Rao, C. and Rao, A. (1999) Characterization of indigenous glauconitic sandstone for its potassium-supplying potential by chemical, biological, and electroultrafiltration methods. Soil Science and Plant Analysis 30: 1105-1117.

Ringqvist, L., Holmgren, A. and Oborn, I. (2002) Poorly humified peat as an adsorbent for metals in wastewater. Water Research (Oxford) 36 (9): 394-2404.

Silber, A., Bar-Yosef, B., Suryano, S. and Levkovitch, I. (2012) Zinc adsorption by perlite: Effects of $\mathrm{pH}$, ionic strength, temperature, and pre-use as growth substrate. Geoderma 170: 159-167.

Singh, D., Prasad, G. and Rupainwar, D. (1996a). Studies on the removal of $\mathrm{Cr}(\mathrm{VI})$ from waste-water by feldspar. J. Chem. Technol. Biotechnol. 53: 127-131

Singh, D., Prasad, G. and Rupainwar, D. (1996b) Adsorption technique for the treatment of As(V)-rich effluents. Colloids Surf. A—Physicochem. Eng. Aspects 111: 49-56

Smith, E., Lu, W., Vengris, T. and Binkiene, R. (1996) Sorption of heavy metals by Lithuanian glauconite. Water Research (Oxford) 30 (12): 2883-2892.

Tahir, S. and Rauf, N. (2004) Removal of Fe(II) from the wastewater of a galvanized pipe manufacturing industry by adsorption onto bentonite clay. Journal of Environmental Management 73 (4): 285-29 


\title{
بعض الخصائص الادمصاصية لخام الجلوكونيث المصري \\ محمد عبد الفتاح محمد عيد الزي \\ قسم الار اضي ـ كلية الزر اعة ـ جامعة عين شمس ـ القاهرة ـ مصر.
}

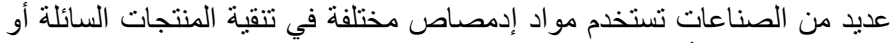

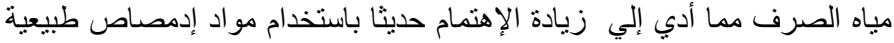

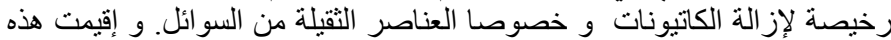

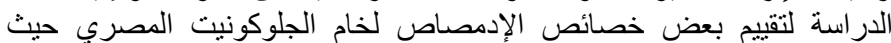

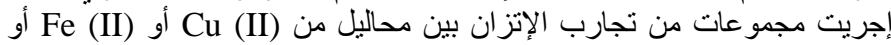

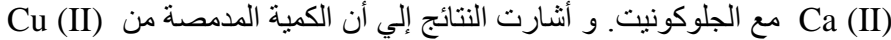

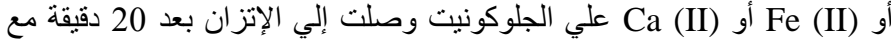

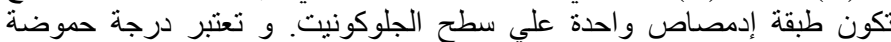

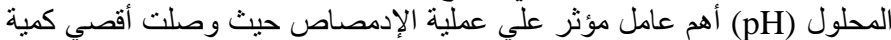

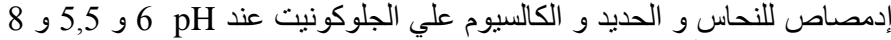

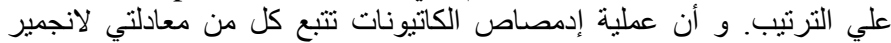

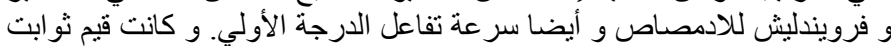

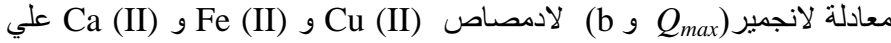

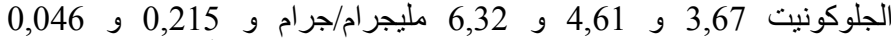
و 0,062 لتر/مليجر ام علي الترتيب. و النتائج السابقة تدل علي أن أن خام الجلوكونيت

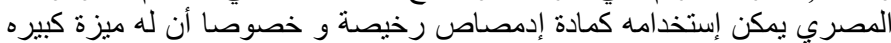
و هي قو امه الرملي الطميي الذي يسهل إستخدامه كمرشح رملي أيضا.
\end{abstract}

